\title{
Research
}

\section{Deciding Where to Burn: Stakeholder Priorities for Prescribed Burning of a Fire-Dependent Ecosystem}

\author{
$\underline{\text { Jennifer K. Costanza }}^{1,2}$ and $\underline{\text { Aaron Moody }}^{1}$
}

\begin{abstract}
Multiagency partnerships increasingly work cooperatively to plan and implement fire management. The stakeholders that comprise such partnerships differ in their perceptions of the benefits and risks of fire use or nonuse. These differences inform how different stakeholders prioritize sites for burning, constrain prescribed burning, and how they rationalize these priorities and constraints. Using a survey of individuals involved in the planning and implementation of prescribed fire in the Onslow Bight region of North Carolina, we examined how the constraints and priorities for burning in the longleaf pine (Pinus palustris) ecosystem differed among three stakeholder groups: prescribed burn practitioners from agencies, practitioners from private companies, and nonpractitioners. Stakeholder groups did not differ in their perceptions of constraints to burning, and development near potentially burned sites was the most important constraint identified. The top criteria used by stakeholders to decide where to burn were the time since a site was last burned, and a site's ecosystem health, with preference given to recently burned sites in good health. Differences among stakeholder groups almost always pertained to perceptions of the nonecological impacts of burning. Prescribed burning priorities of the two groups of practitioners, and particularly practitioners from private companies, tended to be most influenced by nonecological impacts, especially through deprioritization of sites that have not been burned recently or are in the wildland-urban interface (WUI). Our results highlight the difficulty of burning these sites, despite widespread laws in the southeast U.S. that limit liability of prescribed burn practitioners. To avoid ecosystem degradation on sites that are challenging to burn, particularly those in the WUI, conservation partnerships can facilitate demonstration projects involving public and private burn practitioners on those sites. In summary, an increased understanding of stakeholder perspectives can provide insight into the potential long-term consequences of current fire management and thus facilitate effective ecosystem conservation.
\end{abstract}

Key Words: collaborative conservation; fire management; longleaf pine; management liability; risk; wildfire; wildland-urban interface

\section{INTRODUCTION}

Coordination of diverse conservation interests into multistakeholder cooperative partnerships is an increasingly common model for ecosystem management (Wondolleck and Yaffee 2000, Keough and Blahna 2006). Partnerships are intended to bridge gaps among varied stakeholders and help arrive at conservation actions and outcomes that are mutually beneficial or acceptable (Keough and Blahna 2006). Although members of a partnership may agree on common conservation goals, the agencies or individuals involved typically differ in their management abilities and perspectives. Successful collaboration among stakeholders depends in part on a mutual understanding of the others' points of view (Wondolleck and Yaffee 2000). It is particularly important to assess the differences in perspectives among management entities in areas where conservation partnerships have been established to manage fire-dependent ecosystems, because of the costs, risks, and logistical challenges associated with managing fire.

Several conservation partnerships have been established to restore fire-dependent ecosystems such as grasslands, longleaf pine, and ponderosa pine forests by implementing wildland fire use activities such as prescribed burning and letting

${ }^{1}$ University of North Carolina at Chapel Hill, ${ }^{2}$ currently: North Carolina State University 
wildfires burn (for example, McDonald 2002, Romme et al. 2003, Compton et al. 2006). Partnerships face challenges in conducting fire use at levels required to maintain or restore ecosystems (Allen et al. 2002, Van Lear et al. 2005). Constraints such as the cost of implementing prescribed burning and shortage of trained personnel can limit the use of fire (Cleaves et al. 2000). In addition, there is potential for damage to human health or property if smoke or fire spread to populated areas. In landscapes that contain a mixture of protected, residential, and commodity producing lands, fire use is particularly constrained because of the wildland-urban interface (WUI). The WUI is defined as the area where homes and other structures meet or intermix with natural vegetation. In the WUI, fear of liability for damage to human health or property could decrease the likelihood of letting wildfires burn or using prescribed fire, especially because residents tend to have negative perceptions of fire use as a management tool (Winter and Fried 2000, McCaffrey 2004, Schindler 2007). Conversely, suppressing wildfires or failing to implement burning also carries longer term increase in risk of negative effects from future wildfires because of fuel accumulation. Avoiding short-term damages that could result from fire use may be more compelling to land managers than conducting fire management, which may have benefits that are poorly quantified and realized over the long term (Donovan and Brown 2007).

Perception of the costs, risks, challenges, and benefits of fire use may vary among stakeholders, presenting additional challenges to the use of prescribed burning in a multistakeholder framework. Public agencies and private conservation organizations differ in the degree to which longterm ecological goals are emphasized in management practices. However, both are known to manage their land to achieve long-term ecological benefits and to participate in cooperative conservation efforts to do so (Compton et al. 2006). In addition, both public agencies and conservation organizations are likely to be proactive in their use of fire in the interest of long-term maintenance of ecosystem and habitat quality. For example, the U. $\mathrm{S}$. Department of Defense uses prescribed burning to maintain and restore habitat quality in longleaf pine ecosystems (Rosenzweig 2003). In addition, public agencies are usually the ones that bear the cost of wildfire suppression (Yoder and Blatner 2004), and therefore may be more inclined to use prescribed fire to reduce the low, but ever-present risk of catastrophic wildfire. Furthermore, recent federal legislation that recommends fire use as a tool to minimize the effects of wildfires may serve to promote fire use in public agencies (Healthy Forests Restoration Act 2003, O'Laughlin 2005). In contrast, small, nonindustrial private companies may focus on the more immediate risks from fire use because they are more likely to be contracted to manage lands over shorter time periods than other land managers (Yoder and Blatner 2004).

In contrast to the western or midwestern United States, where most other studies of stakeholder perceptions of fire use have been conducted, management of fire-dependent ecosystems in the southeastern U.S. overwhelmingly involves the use of prescribed burning, and more burning is done in the region than in any other part of the country (Haines et al. 2001). Therefore, the capacity of land managers to conduct burning has direct implications for the long-term persistence of southeastern ecosystems. In addition, the Southeast contains the largest land area in WUI (Radeloff et al. 2005). Therefore, the risks, costs, and logistical challenges described previously, in combination with dense settlement and land use patterns, present numerous limitations to burning in the Southeast, and especially inhibit burning across large extents necessary for ecosystem restoration and management (Cleaves et al. 2000, Van Lear et al. 2005).

In response to the unique challenges in the Southeast, all states in the region have laws that limit liability of trained professionals who implement prescribed burning. Florida was the first state to enact such legislation in 1990 , following a court case in which a landowner was found liable for a death caused by an escaped prescribed burn (Brenner and Wade 2003). The Florida legislation passed the Prescribed Burning Act to recognize prescribed burning as an ecological necessity and ensure that property owners or trained professionals who conduct prescribed burning in accordance with guidelines in the Act should not be held liable for damage unless simple negligence can be proven (Sun 2006). Since 1990, all southeastern states have passed simple negligence laws, and five, i.e., Florida, Georgia, Louisiana, Mississippi, and North Carolina, are the only states in the U.S. with legislation that explicitly recognizes prescribed burning as a beneficial activity (Yoder et al. 2003). Florida's law was revised in 1999 to state that no liability should be assigned unless gross negligence, or reckless disregard for the consequences of the 
prescribed burn, is proven (Sun 2006). In addition to legislation, statewide prescribed fire councils have been established in all southeastern states as coalitions among public agencies, private organizations, and individuals to promote the appropriate use of prescribed fire and overcome barriers to burning (Coalition of Prescribed Fire Councils, www.prescribedfire.net). Given the amount of prescribed burning taking place in the Southeast, its impact on ecosystems over regional scales, and the legal environment in which burning is conducted, it is important to understand how decisions are made regarding fire use in the region.

We used surveys to investigate how two groups of stakeholders who are involved in a regional multiagency conservation partnership differ in their prioritization of land for prescribed burning of the longleaf pine ecosystem. These two groups were prescribed burn practitioners (hereafter, practitioners) from public agencies, and practitioners from nonindustrial private forestry companies. We chose to examine how these stakeholders prioritize land, and the rationales behind those priorities, specifically to explicate the priorities and rationales that are often only implicit as multiple stakeholders negotiate around the question of when and where to burn. Unearthing this process will improve the likelihood that management objectives will be understood, supported, and met (Hiers et al. 2003). We compared prescribed burning priorities of these two groups with priorities identified by nonpractitioners, i.e., ecologists who have knowledge of the landscape and ecosystem, but who are not directly involved in burning, and therefore not culpable for the potential outcomes of burning. Specifically, we asked (1) What is the relative importance of factors that constrain prescribed burning in a regional landscape of intermixed rural residential, protected areas, and commodity producing lands? (2) Do stakeholder groups differ in the criteria and rationales they use to prioritize sites for burning? In particular, do groups differ in the degree to which their criteria and rationales are motivated by potential ecological impacts vs. nonecological impacts of prescribed burning?

Based on literature showing the negative opinion of prescribed burning by WUI residents (Winter and Fried 2000, McCaffrey 2004), as well as the potential for damage to human property, we expected that development near prospective burned areas would be the most important constraint on prescribed burning. Because of differences in liability, legislation, and risk described earlier, we predicted that groups would differ in the criteria and rationales they use to prioritize burning. We expected that, compared with nonpractitioners and practitioners from public agencies, practitioners from private forestry companies would use criteria and rationales influenced more by short-term, nonecological consequences. Furthermore, because they are ecologists and do not implement burning themselves, we expected that nonpractitioners would rely more on potential ecological impacts and less on nonecological impacts when they set priorities than the two groups of practitioners. Our results improve our understanding of how different stakeholder groups make decisions about prescribed burning in the Southeast, which will inform collaborative management efforts in fire-dependent ecosystems.

\section{METHODS}

\section{The longleaf pine ecosystem}

Prescribed burning across landscapes plays a critical role in conservation and management of longleaf pine (Pinus palustris) savannas and woodlands in the southeastern U.S. (Van Lear et al. 2005). The longleaf pine ecosystem was once the dominant habitat in the southeastern U.S. along the coastal plain and outer piedmont from Texas to Virginia (Frost 1993). Longleaf pine ecosystems likely burned every one to three years prior to European settlement, and both lightning and Native Americans were ignition sources (Frost 2006). Fires were usually of low intensity, burning understory grasses and maintaining a relatively open midstory. When burned frequently, the understory plant communities in longleaf pine ecosystems have among the highest levels of understory plant species richness in the world (Peet and Allard 1993). With increased time since the last burn, plant growth and pine needle accumulation in the understory, along with infill of woody plants in the midstory, lead to a buildup of fuels and increased potential for higher intensity fires (Varner et al. 2005).

Because of widespread timber harvesting and fire suppression, longleaf forests have been severely degraded and fragmented, reducing this forest type to only $3 \%$ of its pre-European settlement range (Frost 1993). As a result, populations of species such as the endangered Red-cockaded Woodpecker (Picoides borealis) that depend on longleaf pine 
habitat have declined (Van Lear et al. 2005). This decline has prompted Noss and others (1995) to designate longleaf ecosystems as "critically endangered", and others to call for large scale restoration efforts involving prescribed burning to conserve and restore habitat connectivity in the ecosystem (Landers et al. 1995, V an Lear et al. 2005, Hoctor et al. 2006). Partnerships among private and public stakeholders are essential for overcoming barriers to burning and facilitating prescribed burning in longleaf pine ecosystems (Van Lear et al. 2005, America's Longleaf 2009).

\section{Onslow Bight region, partnership, and stakeholders}

We conducted our study in the Onslow Bight, a region of the North Carolina (NC) coastal plain where a multiagency partnership has been established for conservation of longleaf pine (Fig. 1). The Onslow Bight covers 1.23 million hectares, from the inner coastal plain to the barrier islands. Prior to European settlement, an estimated 659,000 hectares, or $54 \%$ of the landscape, was covered in longleaf pine, much of it wet or mesic longleaf pinewiregrass savanna (C. C. Frost and J. K. Costanza, unpublished data). Other portions of the Onslow Bight were predominantly pond pine pocosin, wet hardwood forest, coastal dune or marsh. Today, approximately $19 \%$ of the landscape is longleaf pine, $15 \%$ is pocosin, and $23 \%$ is a mixture of other communities, including bottomland forest, marsh, and coastal dune vegetation (Southeast Gap Analysis Project 2008). Managed pine plantations cover $22 \%$ of the Onslow Bight, and $21 \%$ is either developed or has been converted to agriculture (Southeast Gap Analysis Project 2008). The 12 counties in the Onslow Bight region had a combined population of 886,000 in 2000 (U.S. Census Bureau 2000). Brunswick County is experiencing one of the highest population growth rates in the United States currently, and three other counties are also in the top $20 \%$ of the state for projected future growth (NC OSBM 2008). Approximately $25 \%$ of the region is classified as WUI (Radeloff et al. 2005).

The current fire regime in the Onslow Bight is dominated by prescribed burning. Since 2000, an average of approximately 20,000 hectares per year have been treated with prescribed fire in the landscape, mainly on land owned by large land management agencies including Marine Corps Base Camp LeJeune, Croatan National Forest, and game lands managed by the NC Wildlife Resources Commission. Of the sites that have been prescribe burned since $2000,56 \%$ are currently longleaf pine vegetation, or are on soils that could support longleaf pine communities if restored (Southeast Gap Analysis Project 2008, C. C. Frost and J. K. Costanza, unpublished data). During the same period, wildfires burned approximately 2000 hectares per year on average in all vegetation types on public and private land combined (NC Division of Forest Resources, unpublished data). However, large wildfires do occur in the region, and a 9900 ha wildfire burned in 1994 (U.S. Forest Service, unpublished data).

Land management agencies working in the Onslow Bight differ in their primary goals, which range from management of wildlife habitat, to forestry, to military training. In 2005, with support from The Nature Conservancy's Fire Learning Network (ww w.tncfire.org/training usfln.htm), several agencies formed the Onslow Bight Fire Partnership (OBFP). The mission of the OBFP is to be a partnership that "will work to increase the capacity for and reduce obstacles to conducting prescribed burning" (OBFP, unpublished document, p. 1). Agencies participating in the OBFP include: U.S. Marine Corps Camp LeJeune (U.S. Department of Defense), Croatan National Forest (U.S. Forest Service), Cedar Island National Wildlife Refuge (NWR, U.S. Fish and Wildlife Service), the NC Wildlife Resources Commission (NC WRC), and The Nature Conservancy (TNC). Collectively, these agencies manage $16 \%$ of the landscape (Fig. 1). Aside from these agencies, there are several small private forestry consultants and fire contractors in the region who conduct prescribed burning on land owned by individuals and private landowners such as hunting clubs. Although they have not been formal participants in the OBFP, some contractors have attended partnership meetings. Encouraging use of prescribed fire on private lands is a goal of the OBFP (OBFP, unpublished document). Many contractors and agency professionals are members of the NC Prescribed Fire Council, a statewide organization (www.ncprescribedfirecouncil.org).

To capture potential differences in viewpoints regarding prescribed burning in the Onslow Bight, we separated the stakeholders in the region into three groups for the purposes of our survey: prescribed burn practitioners from agencies, practitioners from private companies, and nonpractitioners. Nonpractitioners included individuals 
Fig. 1. The Onslow Bight landscape. TNC stands for The Nature Conservancy, WRC is the North Carolina Wildlife Resources Commission, and NWR means National Wildlife Refuge.

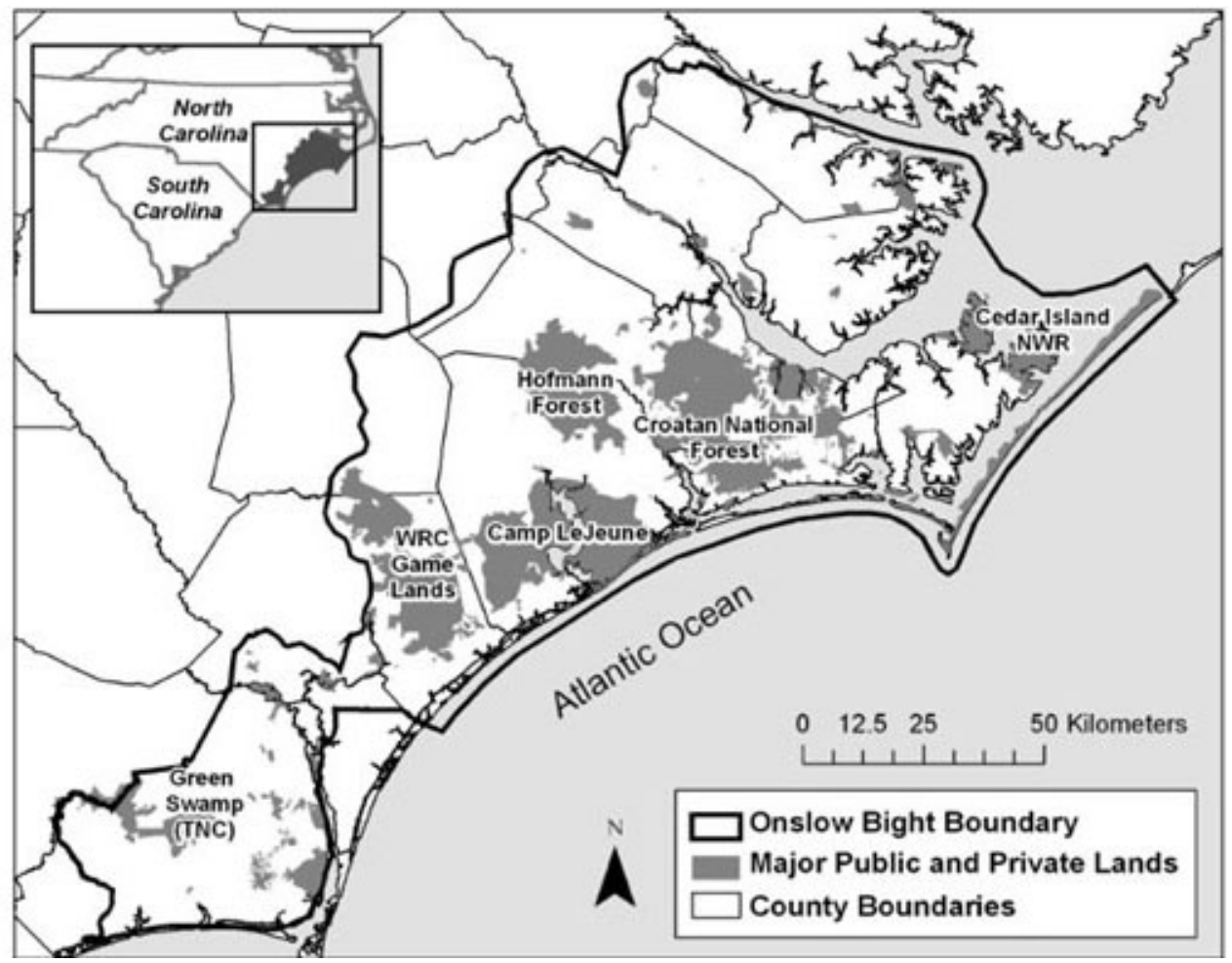

who provide input to burn managers or fire contractors, but do not directly prioritize or themselves conduct prescribed burning activity. This group included academic researchers as well as botanists, wildlife biologists and others who may work in the same agencies as burn practitioners. The other two groups included private and agency individuals who plan and conduct prescribed burning. Practitioners from private companies included respondents who work for private contractors. Agency practitioners included those who work directly for public agencies or for private conservation organizations that manage their own land. We chose to group these two because of the small number of people affiliated with conservation organizations who have knowledge of fire in the Onslow Bight region. Although conservation organizations may differ in their overall missions from public agencies, the two types of organizations have been the most active participants in the OBFP, and have successfully worked together to share knowledge about prescribed burning. In addition, both public agencies and conservation organizations own the land they manage. Thus, we assumed they would share similar views on the constraints and priorities for burning in the Onslow Bight.

\section{Surveys}

Prior to conducting the survey, we conducted three focus groups during a meeting of the OBFP in summer 2007. A total of 15 people representing all stakeholder groups participated. Participants were asked to describe the criteria they use to determine which areas get priority for burning, as well as some of the constraints they face when burning. The result was a set of constraints and criteria that are used to determine priorities for burning, which we used as a starting point for developing an in-depth online survey. 
The surveys asked respondents to indicate the relative importance of each of a series of predefined constraints to burning that we identified from the focus group discussions. Respondents were also given a list of predefined ecological and nonecological criteria and were asked to indicate which are important for prioritizing sites for burning, according to their knowledge or experience (Table 1). Respondents were then asked follow-up questions regarding the rationales behind their top five ranked criteria. Rationales mentioned during the focus groups were listed as potential answers on the survey, and were related to ecological and nonecological impacts of burning, as well as other potential reasons for criteria, such as agency mandate and funding sources. For example, respondents who indicated that the "location of the wildland-urban interface on or near a site" was one of the top five criteria for determining prescribed burning priorities were asked whether they agreed or disagreed with potential rationales behind those criteria. For the WUI, potential rationales included: "Fuel buildup in the wildland-urban interface increases risk of wildfire", and "Smoke is difficult to manage in the wildland-urban interface". For all questions, respondents were given an option to add answers not appearing in the predefined list (see Appendix 1 for a sample of questions from the online survey).

The surveys and data collection were administered in spring 2008 via Qualtrics, a set of online survey tools including secure data storage and advanced features such as the ability to automatically skip questions that do not pertain to certain respondents (www.qualtrics.com). Because our survey population consisted of professionals with access to the Web and e-mail, an Internet survey was well suited for our study (Dillman et al. 2009). To sample the three stakeholder groups, we obtained e-mail addresses of individuals who had participated in or attended meetings of the OBFP or the NC Prescribed Fire Council and e-mailed a link to the online survey. In the survey, we also asked respondents for names of other individuals to whom we could e-mail the survey link. We recognize that by limiting our sample mainly to participants in the OBFP and NC Prescribed Fire Council, we are potentially missing other individuals in the region who would fit into one of our stakeholder groups. For example, our study likely misses private practitioners who are not affiliated with either of the organizations. However, because our intent was to study prescribed burning priorities in the context of collaborative conservation, we believe that including individuals who associate regularly with other stakeholders in the landscape was appropriate here. A follow-up study could specifically target the entire population of private practitioners in the Onslow Bight.

The OBFP was not directly involved in implementing this study aside from accommodating focus groups during one of its meetings, and sharing e-mail addresses of its participants.

\section{Analysis}

Using analysis of variance (ANOVA) tests, we examined the importance value of each constraint. We also used chi-square and Fisher's exact tests to examine differences among stakeholder groups for each criterion. We chose these tests rather than multivariate techniques such as factor analysis or structural equation modeling to avoid the loss of meaning in data that often results from such analysis, especially when using datasets with small sample sizes and numerous variables. The followup questions in the web survey allowed an in-depth examination of the rationales for each criterion. Because respondents were only asked follow-up questions for criteria they ranked in the top five, we analyzed follow-up questions only for criteria that more than half of all respondents indicated were important. We used an alpha level of 0.05 for all statistical tests. All analysis was done using R ( R Development Core Team 2008).

\section{RESULTS}

The survey was sent to 162 people, including 39 nonpractitioners, 67 practitioners from agencies, and 56 practitioners from companies. A total of 104 responses were received, 87 of which were complete and included in this analysis. Of these, 26 responses were from nonpractitioners $(67 \%$ of all nonpractitioners contacted), 40 from practitioners who represented agencies $(60 \%$ of agency representatives), and 21 from practitioners representing private companies $(38 \%$ of private company representatives). Respondents included 35 respondents from state agencies, 17 from federal agencies, one from a local agency, and one from a conservation organization. There were 19 responses from independent contractors, and nine who worked 
Table 1. Ecological and nonecological burn priority criteria named by focus group participants and used in the online surveys, as well as criteria that were added by survey respondents.

\section{Ecological:}

Overall ecosystem health of a site

Whether a site contains threatened or endangered species

Whether a site is habitat for Red-cockaded Woodpeckers (Picoides borealis)

Whether a site experienced frequent fire during presettlement

Presence of undesired exotic plants at a site

Nonecological:

Time since the last burn on a site

Presence of firebreaks at a site

Location of the wildland-urban interface (WUI) on or near a site

Whether a site is being managed for timber

Proximity of a site to other burned sites

Added by respondents ${ }^{\dagger}$ :

Soil type (1)

Potential for pine straw production (1)

${ }^{\dagger}$ Number in parentheses indicates the number of respondents who named the criterion.

for private companies. The remaining respondents were from academia or were unemployed. There was a lower response rate from private practitioners compared with the other groups. However, because we only made statistical comparisons among groups using chi-square tests, which are based on proportions of respondents and not the variance in responses, we did not need to correct for differences in sample sizes. Furthermore, we have no reason to believe that the subset of private practitioners who responded differs from nonrespondents.

\section{Constraints}

The most important constraint for all respondents was the presence of development near areas to be burned (Fig. 2). Inappropriate weather conditions, smoke management regulations, high fuel loads, and shortage of resources such as money or equipment were also highly ranked. The other six constraints were given lower rankings (Fig. 2). 
Fig. 2. Constraints on burning and their mean importance for all respondents.

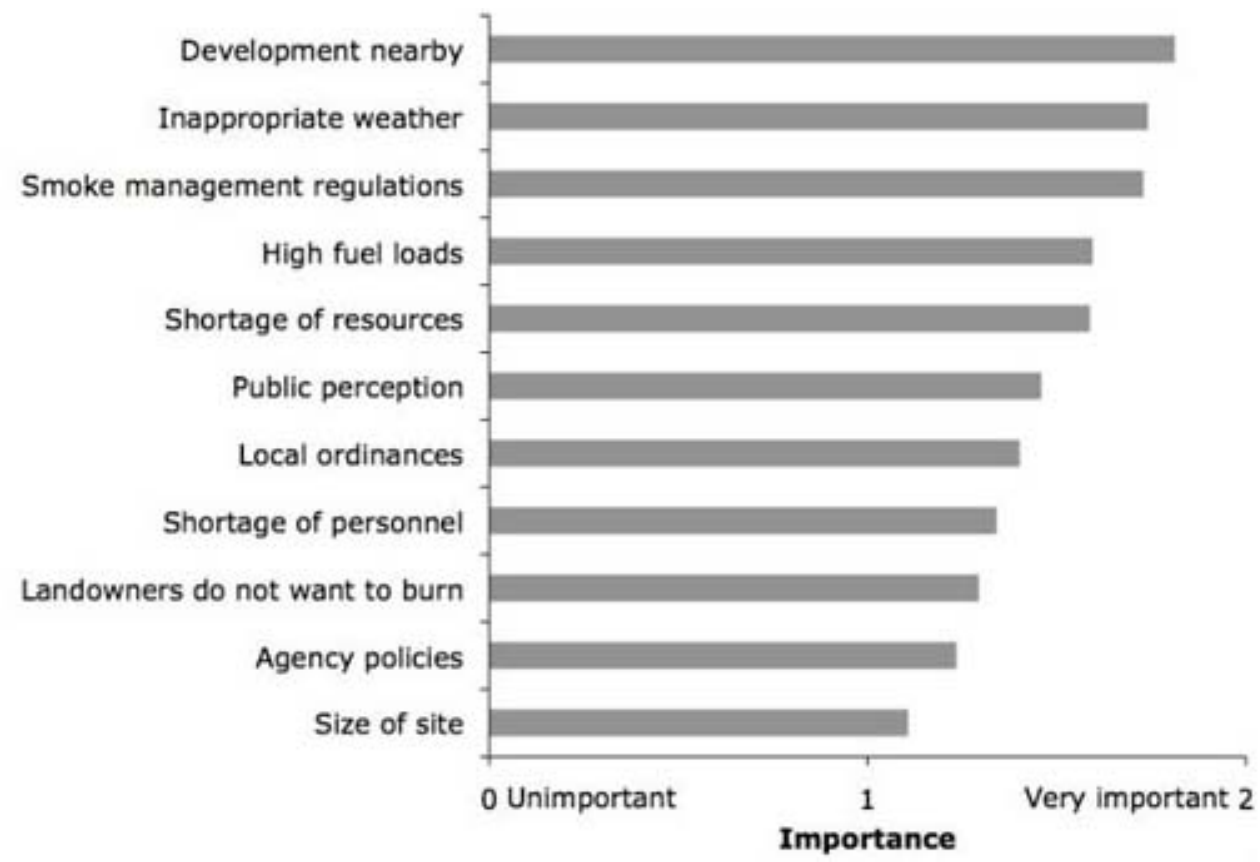

\section{Criteria for prioritization}

Respondents added several criteria that were not in the list provided in the survey. In some cases, the additional criteria were restatements of predefined criteria. For example, we considered "presence of a diverse understory" the same as the predefined "overall ecosystem health". There were two criteria added by respondents that were distinct from the list provided in the survey (Table 1).

The two criteria named as important by the greatest number of respondents were (1) the time since a site was last burned, and (2) the overall ecosystem health of a site (Fig. 3). Other important criteria were: (3) whether a site occurs in the WUI, (4) whether there are firebreaks surrounding a site, (5) whether threatened or endangered species (aside from Redcockaded Woodpeckers) are found at a site, and (6) whether Red-cockaded Woodpeckers occur at a site. For these six criteria, we subsequently analyzed respondents' stated rationales for considering them important. The other four criteria were named by fewer than half of the total respondents (Fig. 3).
For 6 out of 10 criteria, groups did not differ in the proportion of respondents indicating that the criterion was important (Fig. 3). These included the two most consistently rated criteria: the time since a site was last burned, and the overall ecosystem health of a site. Two nonecological criteria, the location of the WUI $\left(\mathrm{X}^{2}(2, \mathrm{~N}=87)=6.70, p=\right.$ $0.04)$, the presence of firebreaks $\left(\mathrm{X}^{2}(2, \mathrm{~N}=87)=\right.$ $18.48, p<0.001)$, and whether the site is managed for timber $\left(\mathrm{X}^{2}(2, \mathrm{~N}=87)=15.65, p<0.001\right)$ were rated as important by private practitioners more frequently than the other two groups. Conversely, nonpractitioners and practitioners from agencies named whether a site experienced frequent fire prior to European settlement as an important criterion significantly more often than practitioners from private companies $\left(\mathrm{X}^{2}(2, \mathrm{~N}=87)=8.44, p<0.02\right)$.

The priority of a site depended on the amount of time since it was last burned, with sites burned 2 to 15 years ago having the highest priority (ANOVA with Tukey HSD groups, $\left.F_{6,469}=61.92, p<0.001\right)$. Regardless of stakeholder group, more respondents said that sites with good ecosystem health are higher priorities for burning than sites with poor health 
Fig. 3. Proportion of survey respondents who indicated each criterion is important for determining burn priorities. Bars represent proportions of the overall survey population, while circles, crosses, and diamonds are only shown for criteria that show significant differences among stakeholder groups.

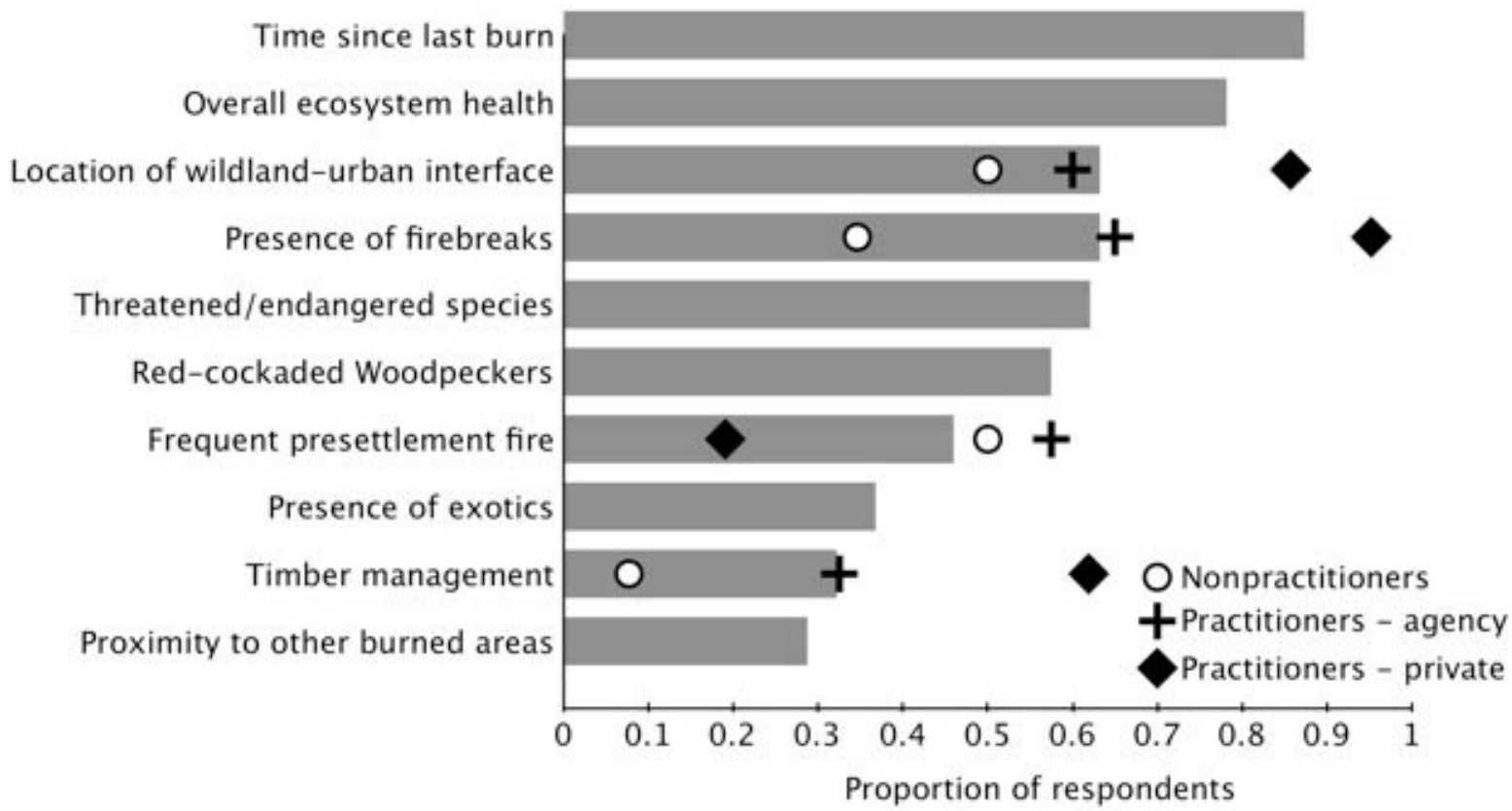

(overall proportions were $69.8 \%$ and $30.2 \%$, respectively). Stakeholder groups differed in whether they considered sites within the WUI to be priorities over sites outside the WUI. Compared with practitioners from private companies, a significantly higher proportion of practitioners from agencies focused on sites within the WUI (overall $\mathrm{X}^{2}$ $(2, \mathrm{~N}=43)=11.478, p=0.003$; agency practitioners and private practitioners Fisher's exact test: $\mathrm{N}=33$, $p=0.001)$.

\section{Rationales behind criteria}

Of the 36 rationales behind the top six priority criteria that were presented on the survey, just over half, or 19, were named by more than $33 \%$ of respondents who were asked about them. To be concise we discuss only these 19 rationales here. Seven rationales were related to ecological impacts of fire, eight related to impacts to people or property, and four to other types of rationales, including those related to agency mandates or funding. Rationales implying ecological impacts were related to the time since a site was last burned, overall ecosystem health, the presence of firebreaks, threatened and endangered species, and Red-cockaded woodpeckers. For all of these rationales, there were no significant differences among stakeholder groups in the proportion of respondents who considered them important (Fig.4). Therefore, based on the data gathered, the three stakeholder groups perceive the ecological impacts of burning similarly.

There were significant differences among stakeholder groups for four of the eight rationales related to impacts to people or property (Fig. 5). Two of these were related to reduced risk in recently burned areas. Compared with nonpractitioners, more respondents from both practitioner groups agreed that fire behavior is more predictable in recently burned areas (overall $\mathrm{X}^{2}(2, \mathrm{~N}=68)=$ 13.401, $p=0.001$ ) and smoke management is easier in these areas (overall $\mathrm{X}^{2}(2, \mathrm{~N}=68)=11.442, p=$ $0.003)$. The other two rationales with differences among stakeholder groups relate to increased risk in the WUI, and showed significant differences between the two groups of practitioners. In 
Fig. 4. Proportion of survey respondents in each stakeholder group who agreed with each rationale related to ecological impacts of fire. There were no significant differences among groups for any of these rationales.

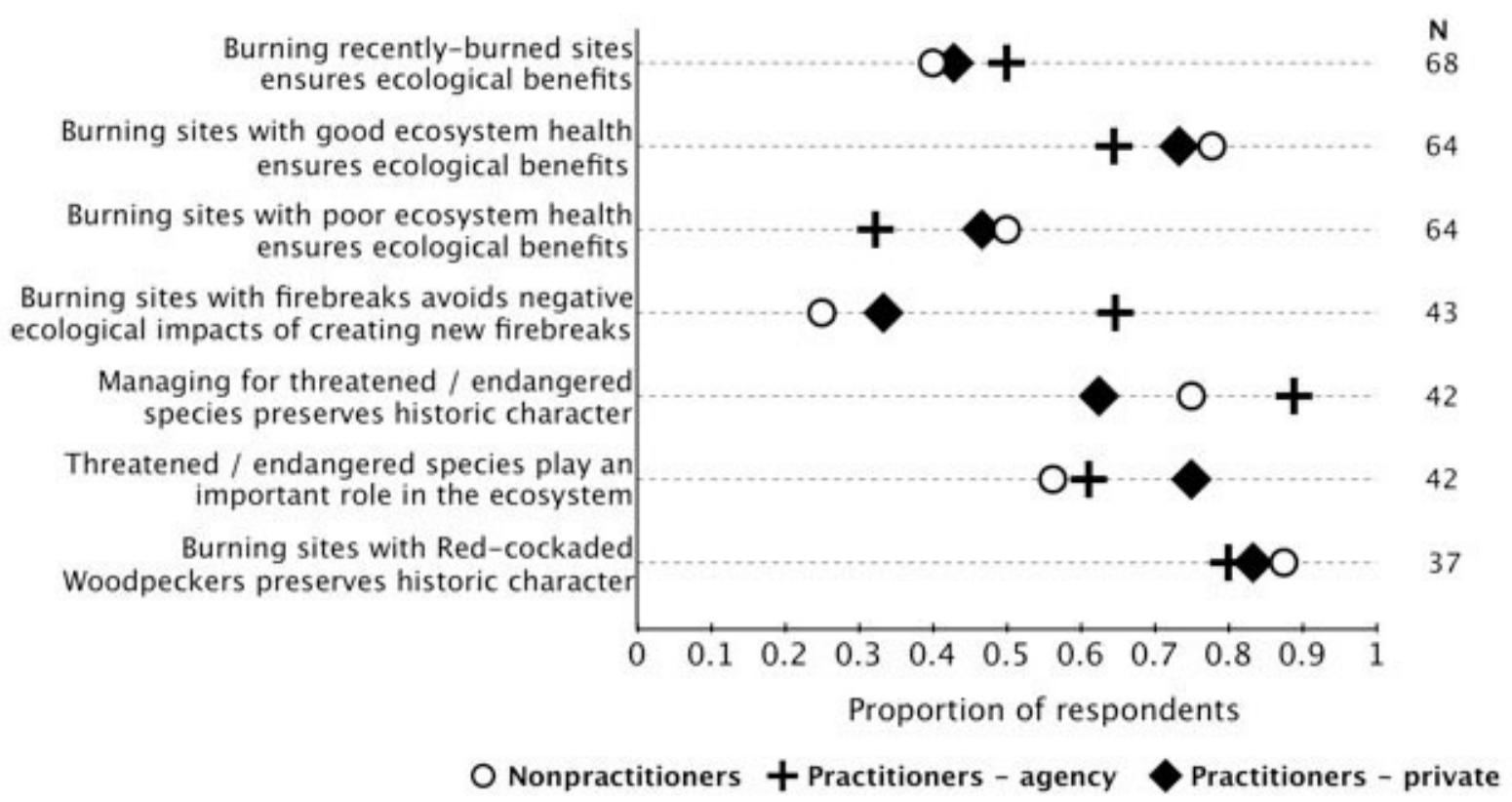

comparison to private practitioners, significantly more practitioners from agencies agreed that fuel buildup in the WUI increases risk of wildfire (overall Fisher's exact test: $\mathrm{N}=43, p=0.03$ ). In contrast, significantly more practitioners from private companies than from agencies named the difficulty with smoke management in the WUI (overall Fisher's exact test: $\mathrm{N}=43, p=0.02$ ).

There were no differences among groups for the four other rationales identified as important by greater than $33 \%$ of respondents. Three of these rationales were related to agency goals and mandates: (1) My or my agency's primary goal is to manage for Red-cockaded woodpeckers (named by $76 \%$ of respondents); (2) Either my agency or I am mandated to manage for threatened or endangered species (55\%); (3) Either my agency or I receive funding to manage for Red-cockaded Woodpeckers $(35 \%)$. The fourth rationale was related to reducing costs: Burning sites with firebreaks requires less investment $(53 \%)$.

\section{DISCUSSION}

Others have argued that the success of collaborative conservation partnerships depends in part on the ability of diverse stakeholders to understand one another's interests (Wondolleck and Yaffee 2000). Our results highlight the different perspectives that stakeholder groups bring to prioritizing land parcels for fire management. We show that stakeholders differ in the criteria and rationales they use to prioritize prescribed burning. In our study, these differences most often pertained to the nonecological impacts of burning.

Several rationales related to impacts to people or property were named more often by practitioners than nonpractitioners. For example, although all groups identified the ecological benefits of burning recently burned sites, more respondents from the two groups of practitioners agreed that fire behavior is more predictable and smoke management is easier on those sites. These nonecological rationales underlying the preference for burning recently 
Fig. 5. Proportion of survey respondents who agreed with each rationale related to impacts to people or property. P-values are listed for rationales for which there is a significant difference among stakeholder groups.

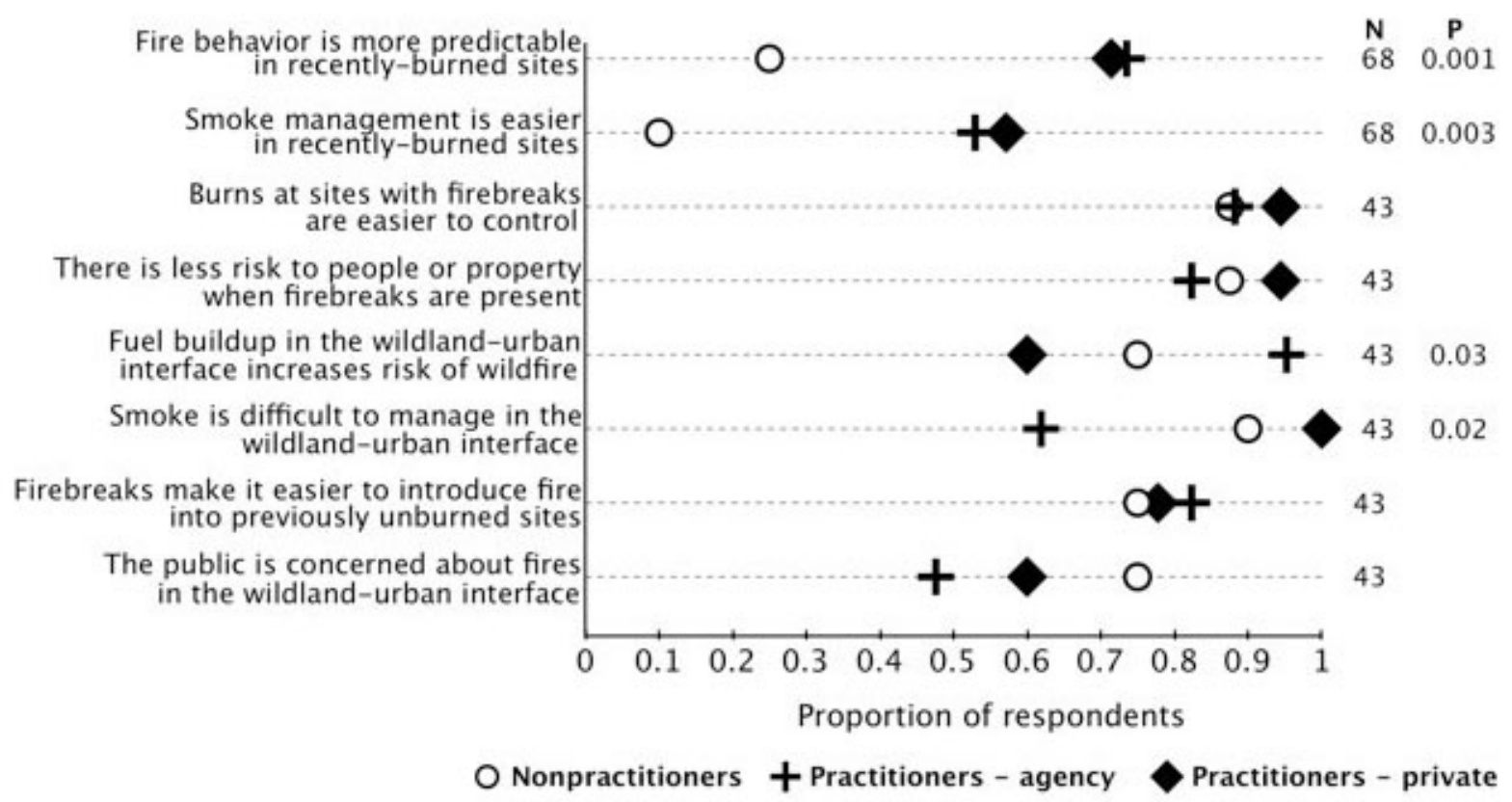

burned sites are consistent with previous research that suggests that practitioners exhibit "certainty bias" when making decisions about whether to implement prescribed burning (Maguire and Albright 2005). Under certainty bias, managers tend to view decisions about prescribed burning as a choice between a risky alternative (implement burning) and an alternative with a fairly certain short-term outcome (do not burn). In reality, both alternatives present risk, and their outcomes are uncertain. Prescribed burning carries risk of damage to nearby property, harm to human health from smoke, or damage to existing longleaf pine trees if fires become too hot (Varner et al. 2005). Risks associated with not burning include loss of biodiversity, and growth of a dense, flammable woody understory, which can lead to hotter, more damaging fires than the low intensity fires that occur in frequently burned stands (Brockway and Lewis 1997, Varner et al. 2005). In contrast to practitioners, one reason that nonpractitioners may not identify differences in potential impacts to people or property on recently vs. nonrecently burned sites is that they do not implement burning and thus are not directly responsible for its impacts.

The two groups of practitioners differed from one another in how risks associated with the WUI affected their decisions. Compared with agency practitioners, a higher proportion of practitioners from private companies considered the WUI an important criterion for determining burning priorities, and assigned a higher priority to sites outside the WUI to avoid smoke management problems. Conversely, agency practitioners and nonpractitioners assigned a higher priority to sites inside the WUI. These results suggest that practitioners from private companies have a greater tendency to weight the immediate outcomes from burning in the WUI higher than the long-term potential for wildfire after fuel accumulation due to not burning, which corresponds to a phenomenon in the risk analysis literature called "mental discounting" (Maguire and Albright 2005). Practitioners from private forestry companies generally are under short-term (annual or two-year) 
contracts from private individuals and do not own the land they burn. If they are found negligent, these practitioners can be held liable for damages caused to nearby property by escaped prescribed fires. Neither the landowner nor the burn contractor can be held liable under statutory law for their contributions to fuels that increase future wildfire severity (Yoder and Blatner 2004). Therefore, private burn practitioners are obligated to focus on the short-term consequences of a prescribed burn. This focus is not unexpected, and is consistent with our hypothesis.

In contrast to practitioners from private companies, the consequences of a future wildfire in the WUI are likely greater to agency practitioners for several reasons (Daniel 2007). First, public agencies manage their land over longer time periods than the short-term contracts under which private contractors typically operate. Second, agency practitioners, particularly those from federal agencies, may be obligated to reduce future wildfire risk via prescribed burning if doing so fulfills other agency mandates. For example, if failing to conduct prescribed burns interferes with a federal agency's ability to conserve endangered species habitat, that agency could be held responsible under the Endangered Species Act. Third, public agencies bear primary responsibility for suppressing a wildfire if one occurs, and therefore absorb more of the costs of letting fuel loads accumulate (Yoder and Blatner 2004). For these reasons, there is likely more incentive for practitioners from public agencies to perform prescribed burning to reduce fuel loads for wildfire prevention.

Although our results are broadly consistent with other research on risks and priorities for fire management, by examining the perspectives of three groups of stakeholders in the Southeast U.S., our study provides new insights on the social aspects of fire management. In particular, this research highlights the perspective that practitioners from private forestry contractors bring to prescribed burning. Previous studies have examined risk perceptions of individuals living in the WUI, and found results consistent with the views of the private practitioners surveyed here. People living in hazardous areas tend to accept risk from future wildfire, and are reluctant to perform prescribed burning or other fuel reduction on their own properties, even if they have experienced a large wildfire in the past (Winter and Fried 2000, McCaffrey 2004). Although our study did not include individual landowners, many use contractors to conduct their burning, and landowner priorities and rationales may be reflected in responses given by practitioners from private companies.

Despite the important differences among stakeholder groups seen in our results, there were many similarities. Stakeholders in the Onslow Bight differed little in their perceptions of the constraints to burning. As we hypothesized, development nearby was the most important constraint, indicating that the WUI is the biggest limitation on burning activities. The WUI was also one of the most important criteria for all three stakeholder groups. In addition, counter to our expectations, stakeholder groups tend to use the potential ecological impacts of fire similarly when prioritizing areas to burn. The groups showed no differences in terms of the ecologically related rationales behind all criteria.

We examined the priorities for prescribed burning and the rationales behind those priorities to explore the perspectives that stakeholder groups bring to fire management decisions. Although explicitly determining priorities is important for decision making, stated intentions do not always match observed actions (Daniel 2007). Therefore, a follow-up on this work should examine recent prescribed burning activity of a variety of stakeholder groups and determine how it is influenced by factors such as the location of the WUI and the accumulation of fuels. Another extension of this work should be to incorporate stakeholders from the general public: community groups, government agencies, and other residents with a general interest in conservation. Including those groups could increase our understanding of the public's perception of fire and the complex issues surrounding fire management in the WUI. To further quantify the potential effects of management decisions on the longleaf pine ecosystem, multistakeholder priorities for burning could be modeled spatially in a GIS, and decisions about where to burn under different risk, benefit, and constraint scenarios could be charted for a landscape like the Onslow Bight.

Although recent federal legislation has promoted fuel reduction strategies on federal land, the focus of fire management is still on suppression, with little emphasis on fire use activities such as prescribed burning (Franklin and Agee 2003, Stephens and 
Ruth 2005, Donovan and Brown 2007). Given laws limiting liability of prescribed burning professionals and establishment of statewide prescribed fire councils in the Southeast, the region may be ahead of much of the rest of the country in terms of laws and policies that encourage fire use (Sun 2006; Coalition of Prescribed Fire Councils www.prescri bedfire.net). However, our results suggest that these laws and policies alone may not be sufficient to overcome some barriers to fire management. Especially for private practitioners, liability from burning on these sites may still be significant. The difficulty conducting fire management on longunburned sites and areas in the WUI implies that these sites may face risk of further ecosystem degradation. More widespread laws that further limit liability, similar to Florida's gross negligence law, may help somewhat to facilitate burning on these locations.

Legislation alone likely will not be enough to facilitate fire management on sites that are difficult to burn. The bias of private practitioners against burning sites in the WUI means that these lands are particularly vulnerable to neglect and further degradation because of lack of burning. Furthermore, as residential and urban development spreads, new lands that become part of the WUI will decline as well if they are not burned. Collaborative conservation partnerships can provide an organizational structure within which biases in the prescribed burn regime, such as the ones pointed out here, could be counteracted. The fact that we found both similarities and differences among the perspectives held by stakeholder groups may indicate opportunities for collaboration to promote fire management on sites in the WUI. For example, under the Wyden Amendment (Omnibus Consolidated and Emergency Supplemental Appropriation Act 1999), the U.S. Forest Service can enter into cooperative agreements with private landowners for land management. A demonstration project in the WUI under this Act in which public and private practitioners cooperate to conduct a burn on private land could facilitate future fire management of fire-dependent ecosystems in the WUI. Thus, through improved understanding of stakeholder perspectives on fire management, collaborative partnerships can be more effective vehicles by which to accomplish conservation objectives.
Responses to this article can be read online at: http://www.ecologyandsociety.org/vol16/iss 1/art14/ responses/

\section{Acknowledgments:}

We thank all survey and focus group participants and M. Bucher, T. Steelman, and S. Pohlman for help leading focus groups. Staff at UNC's Odum Institute assisted with the design of survey and focus group instruments, and with statistical analysis. $M$. Brunson, C. C. Frost, S. Pearsall, R. K. Peet, and P. S. White provided helpful feedback on earlier versions of this manuscript. The comments of anonymous reviewers greatly improved the manuscript.

\section{LITERATURE CITED}

Allen, C. D., M. Savage, D. A. Falk, K. F. Suckling, T. W. Swetnam, T. Schulke, P. B. Stacey, P. Morgan, M. Hoffman, and J. T. Klingel. 2002. Ecological restoration of southwestern ponderosa pine ecosystems: a broad perspective. Ecological Applications 12(4):1418-1433.

America's Longleaf. 2009. Range-wide conservation plan for longleaf pine. Prepared by the Regional Working Group for America's Longleaf. [online] URL: http://www.americaslongleaf.net/resources/theconservation-plan/Conservation\%20Plan.pdf.

Brenner, J. D., and D. D. Wade. 2003. Florida's revised prescribed fire law: protection for responsible burners. Pages 132-136 in K. E. M. Galley, R. C. Klinger, and N. G. Sugihara, editors. Proceedings of Fire Conference 2000: The First National Congress on Fire Ecology, Prevention, and Management Miscellaneous Publication No. 13. Tall Timbers Research Station, Tallahassee, Florida, USA

Brockway, D. G., and C. E. Lewis. 1997. Long-term effects of dormant-season prescribed fire on plant community diversity, structure and productivity in a longleaf pine wiregrass ecosystem. Forest Ecology and Management 96:167-183.

Cleaves, D. A., J. Martinez, and T. K. Haines. 2000. Influences on prescribed burning activity and costs 
in the National Forest System. General Technical Report SRS-37. U.S. Forest Service, Asheville, North Carolina, USA.

Compton V., J. B. Brown, M. Hicks, and P. Penniman. 2006. Role of public-private partnership in restoration: a case study. Pages 413-429 in S. Jose, E. Jokela, and D. Miller, editors. Longleaf pine ecosystems: ecology, management, and restoration. Springer, New York, New York, USA.

Daniel, T. C. 2007. Perceptions of wildfire risk. Pages 55-69 in T. C. Daniel, M. S. Carroll, C. Moseley, and C. Raish, editors. People, fire, and forests: a synthesis of wildfire social science. Oregon State University Press, Corvallis, Oregon, USA.

Dillman D. A., J. Smyth, and L. M. Christian. 2009. Internet, mail, and mixed-mode surveys: the tailored design method. John Wiley \& Sons, Hoboken, New Jersey, USA.

Donovan G. H., and T. C. Brown. 2007. Be careful what you wish for: the legacy of Smokey Bear. Frontiers in Ecology and the Environment 5:73-79.

Franklin, J. F., and J. K. Agee. 2003. Forging a science-based national forest fire policy. Issues in Science and Technology 20:59-66.

Frost, C. C. 1993. Four centuries of changing landscape patterns in the longleaf pine ecosystem. Pages 17-43 in S. M. Hermann, editor. Proceedings of the Tall Timbers Fire Ecology Conference, No. 18, The Longleaf Pine Ecosystem: ecology, restoration and management. Tall Timbers Research Station, Tallahassee, Florida, USA.

Frost, C. C. 2006. History and future of the longleaf pine ecosystem. Pages 9-48 in S. Jose, E. Jokela, and D. Miller, editors. Longleaf pine ecosystems: ecology, management, and restoration. Springer, New York, New York, USA.

Haines, T. K., R. L. Busby, and D. A. Cleaves. 2001. Prescribed burning in the south: trends, purpose and barriers. Southern Journal of Applied Forestry 25:149-153.

Healthy Forests Restoration Act. 2003. Public Law 108-148, 16 US Code 6501 et seq.

Hiers, J. K., S. C. Laine, J. J. Bachant, J. H. Furman, W. W. Greene Jr., and V. Compton. 2003. Simple spatial modeling tool for prioritizing prescribed burning activities at the landscape scale. Conservation Biology 17(6):1571-1578.

Hoctor, T. S., R. F. Noss, L. D. Harris, and K. A. Whitney. 2006. Spatial ecology and restoration of the longleaf pine ecosystem. Pages 377-401 in S. Jose, E. Jokela and D. Miller, editors. Longleaf pine ecosystems: ecology, management, and restoration. Springer, New York, New York, USA.

Keough, H., and D. J. Blahna. 2006. Achieving integrative, collaborative ecosystem management. Conservation Biology 20:1373-1382.

Landers, J. L., D. H. Van Lear, and W. D. Boyer. 1995. The longleaf pine forests of the southeast: requiem or renaissance? Journal of Forestry 9:39-44.

Maguire, L. A., and E. A. Albright. 2005. Can behavioral decision theory explain risk-averse fire management decisions? Forest Ecology and Management 211:47-58.

McCaffrey, S. 2004. Thinking of wildfire as a natural hazard. Society and Natural Resources 17:509-516.

McDonald, W. 2002. The Malpai Borderlands Group: building the "radical center". Pages 211-216 in G. K. Meffe, L. A. Nielsen, R. L. Knight, and D. A. Schenborn, editors. Ecosystem management: adaptive, community-based conservation. Island Press, Washington, D.C., USA.

North Carolina Office of State Budget and Management (NC OSBM). 2008. North Carolina County/State Population Projections. Office of State Budget and Management, Raleigh, North Carolina, USA. [online] URL: www.osbm.state.nc. us/ncosbm/facts and figures/socioeconomic data/ population estimates/county projections.shtm.

Noss, R. F., E. T. LaRoe, and J. M. Scott. 1995. Endangered ecosystems of the United States: a preliminary assessment of loss and degradation. Biological report 28. National Biological Service, Washington, D.C., USA.

O'Laughlin, J. 2005. Policy issues relevant to risk assessments, balancing risks, and the national fire plan: needs and opportunities. Forest Ecology and Management 211:3-14. 
Omnibus Consolidated and Emergency Supplemental Appropriations Act. 1999. Public Law 105-277, 16 US Code 1011(a) et seq.

Peet, R. K., and D. J. Allard. 1993. Longleaf pine vegetation of the southern Atlantic and eastern Gulf Coast regions: a preliminary classification. Pages 45-81 in S. M. Hermann, editor. Proceedings of the Tall Timbers Fire Ecology Conference, No. 18, The Longleaf Pine Ecosystem: ecology, restoration and management. Tall Timbers Research Station, Tallahassee, Florida, USA.

R Development Core Team. 2008. R: a language and environment for statistical computing. Foundation for Statistical Computing, Vienna, Austria.

Radeloff, V. C., R. B. Hammer, S. I. Stewart, J. S. Fried, S. S. Holcomb, and J. F. McKeefry. 2005. The wildland-urban interface in the United States. Ecological Applications 15:799-805.

Romme W. H., M. Preston, D. L. Lynch, P. Kemp, M. L. Floyd, D. D. Hanna, and S. Burns. 2003. The ponderosa pine forest partnership: ecology, economics, and community involvement in forest restoration. Pages 99-125 in P. G. Friederici, editor. Ecological restoration of southwestern ponderosa pine forests: a source-book for research and application. Island Press, Washington, D.C., USA.

Rosenzweig, M. L. 2003. Win-win ecology: how the earth's species can survive in the midst of human enterprise. Oxford University Press, Oxford, UK.

Schindler, B. 2007. Public acceptance of wildland fire conditions and fuel reduction practices: challenges for federal forest managers. Pages 37-54 in T. C. Daniel, M. S. Carroll, C. Moseley, and C. Raish, editors. People, fire, and forests: a synthesis of wildfire social science. Oregon State University Press, Corvallis, Oregon, USA.

Southeast Gap Analysis Project. 2008. Southeast GAP Regional Land Cover (NC Subsection). Southeast Gap Analysis Project, Raleigh, North Carolina, USA. [online] URL: www.basic.ncsu.edu/ segap/index.html.

Stephens, S. L., and L. W. Ruth. 2005. Federal forest-fire policy in the United States. Ecological Applications 15:532-542.
Sun, C. 2006. Liability of using prescribed fire on forestlands and state legislation evolution. Pages 225-240 in S. J. Chang and M. A. Dunn, editors. Proceedings of the 35th Annual Southern Forest Economics Workshop. Mississippi State, Mississippi, USA.

U.S. Census Bureau. 2000. Census 2000 Redistricting Data (P.L. 94-171) Summary File: North Carolina. [online]: Census 2000 Redistricting Data.

Van Lear, D. H., W. D. Carroll, P. R. Kapeluck, and R. Johnson. 2005. History and restoration of the longleaf pine-grassland ecosystem: implications for species at risk. Forest Ecology and Management 211:150-165.

Varner, J. M. I., D. R. Gordon, F. E. Putz, and J. K. Hiers. 2005. Restoring fire to long-unburned Pinus palustris ecosystems: novel fire effects and consequences for long-unburned ecosystems. Restoration Ecology 13(3):536-544.

Winter, G., and J. S. Fried. 2000. Homeowner perspectives on fire hazard, responsibility, and management strategies at the wildland-urban interface. Society \& Natural Resources 13:33-49.

Wondolleck, J. M., and S. L. Yaffee. 2000. Making collaboration work: lessons from innovation in natural resource management. Island Press, Washington, D.C., USA.

Yoder, J., and K. Blatner. 2004. Incentives and timing of prescribed fire for wildfire risk management. Journal of Forestry 102:38-41.

Yoder J., M. Tilley, D. Engle, and S. Fuhlendorf. 2003. Economics and prescribed fire law in the United States. Review of Agricultural Economics 25:218-233. 


\section{Appendix 1: Sample of questions from the online survey.}

The following survey questions were administered online; therefore, their format was slightly different than what is presented here. The online version can be viewed at:

http://uncodum.qualtrics.com/SE?SID=SV 2aEua5capUgEE3q\&SVID=Prod

\section{$\underline{\text { A. Constraints }}$}

Based on your experience or knowledge, how important do you think each of the following is in constraining burning activities currently?

\begin{tabular}{|l|l|l|l|}
\hline & Very Important & $\begin{array}{c}\text { Somewhat } \\
\text { Important }\end{array}$ & Unimportant \\
\hline Shortage of trained personnel & & & \\
\hline $\begin{array}{l}\text { Shortage of resources, including money or } \\
\text { equipment }\end{array}$ & & & \\
\hline Smoke management regulations & & & \\
\hline High fuel loads & & & \\
\hline Public perceptions of burning & & & \\
\hline Landowners do not want to burn & & & \\
\hline Size of the site to be burned & & & \\
\hline Local ordinances that restrict burning & & & \\
\hline Inappropriate weather conditions & & & \\
\hline Agency policies that discourage risk-taking & & & \\
\hline $\begin{array}{l}\text { Residential or other development in or near areas } \\
\text { to be burned }\end{array}$ & & & \\
\hline
\end{tabular}

If there are any other factors that constrain burning activities, please list them. 


\section{B. Criteria for prioritizing burning}

Which of the following characteristics are important in determining whether a site (such as a burn unit) has a high priority for burning? Please check all that apply.

(Because the rest of the survey is based on your response to this question, checking at least one site characteristic here is required. All of the other questions in this survey are optional.)

Presence of firebreaks or well-established fire lines at a site/burn unit

Whether a site/burn unit is managed for timber

Overall ecosystem health of a site/burn unit

Presence of red-cockaded woodpeckers

Presence of other threatened or endangered species

Distance to developed or residential land (the wildland-urban interface)

Time since the last burn at a site/burn unit

Presence of undesired exotic or invasive plants

Proximity of a site/burn unit to other burned areas

Experienced frequent fire historically or during presettlement

Other characteristic 1 - please specify:

Other characteristic 2 - please specify:

Other characteristic 3 - please specify:

Other characteristic 4 - please specify: 
Below are the characteristics that you indicated are important for determining burn priorities. Please rank them in order of importance, starting with 1 for the most important characteristic. [In the online version of the survey, only those that were selected in the above question appeared in the list below.]

Presence of firebreaks or well-established fire lines at a site/burn unit

Distance to developed or residential land (the wildland-urban interface)

Time since the last burn at a site/burn unit

Experienced frequent fire historically or during presettlement

Whether a site/burn unit is managed for timber

Presence of undesired exotic or invasive plants

Presence of red-cockaded woodpeckers

Overall ecosystem health of a site/burn unit

Proximity of a site/burn unit to other burned areas

Presence of other threatened or endangered species

$<$ Other characteristic 1>:

$<$ Other characteristic $2>$ :

$<$ Other characteristic $3>$ :

$<$ Other characteristic $4>$ : 


\section{Follow-up questions: rationales}

[The following questions were asked only if the respondent indicated that the corresponding criterion was one of the five most important criteria for determining burning priorities.]

Time Since Last Burn

Please rate the following in terms of their priority for burning.

\begin{tabular}{|l|l|l|l|}
\hline & Lowest priority & Medium priority & Highest priority \\
\hline $\begin{array}{l}\text { Sites that have burned less than 1 year } \\
\text { ago }\end{array}$ & & & \\
\hline Sites that have burned 1-2 years ago & & & \\
\hline Sites that have burned 2-3 years ago & & & \\
\hline Sites that have burned 3-5 years ago & & & \\
\hline Sites that have burned 5-10 years ago & & & \\
\hline Sites that have burned 10-15 years ago & & & \\
\hline Sites that have burned more than 15 \\
years ago
\end{tabular}

Why do you consider the time since a site was last burned to be important for determining burn priorities? Please choose all that apply.

Smoke management is easier in recently-burned sites.

Either I, or my agency, receives funding to burn sites based on the time since they were last burned.

There are more benefits to ecological health when burning in recently-burned sites.

Fire behavior is more predictable in recently-burned sites.

Agency policies mandate that uncharacteristic sites be restored to a more "natural" state. 
There are more benefits to ecological health in sites that have not been recently burned.

If there are any other reasons why time since last burn is important for determining burning priorities, please list them here.

\section{Red-cockaded Woodpeckers}

Why do you consider the presence of red-cockaded woodpeckers to be important for determining burn priorities? Please choose all that apply.

Red-cockaded woodpeckers influence the ecological health of the longleaf pine ecosystem.

Either I, or my agency, receives funding to manage for red-cockaded woodpeckers.

The public cares about red-cockaded woodpeckers.

Burning these sites ensures that their historic or "natural" character is preserved.

Either my or my agency's primary goal is to conserve endangered species or wildlife.

If there are any other reasons why red-cockaded woodpeckers are important for determining burning priorities, please list them here. 


\section{Wildland-urban interface}

Of the options below, which of the following has highest priority for burning? Please choose one.

Sites within the wildland-urban interface

Sites outside the wildland-urban interface

Why do you consider the distance to the wildland-urban interface is important for determining burn priorities? Please choose all that apply.

Either I, or my agency, is mandated to consider the wildland-urban interface.

Either I, or my agency, receives funding to burn in the wildland-urban interface.

Smoke is difficult to manage properly in wildland-urban interface areas.

The public is concerned about fires in wildland-urban interface areas.

Fuel buildup in wildland-urban interface areas increases risk of a wildfire that could damage surrounding homes or property.

If there are any other reasons why the wildland-urban interface are important for determining burning priorities, please list them here.

\section{Other threatened or endangered species}

Why do you consider the presence of threatened or endangered species to be important for determining burn priorities? Please choose all that apply.

Either I, or my agency, receives funding to manage for these species.

Managing for threatened or endangered species preserves the historic character of natural areas.

Threatened or endangered species play an important role in the longleaf pine ecosystem. 
Either I, or my agency, is mandated to manage for these species.

The public cares about threatened and endangered species.

If there are any other reasons why presence of threatened or endangered species is important for determining burning priorities, please list them here.

\section{Timber management}

Why do you consider timber management to be important for determining burn priorities? Please choose all that apply.

Smoke management is easier in sites managed for timber than at other sites.

Either I, or my agency, receives revenue from timber sales.

Fire behavior is more predictable at sites managed for timber than at other sites.

Either I, or my agency, is mandated to manage for timber.

Burning at sites managed for timber also benefits endangered species or the overall ecosystem health of the site.

If there are any other reasons why timber management is important for determining burning priorities, please list them here.

\section{Firebreaks}

Why do you consider the presence of firebreaks or well-established fire lines to be important for determining burn priorities? Please choose all that apply.

Burns at sites with firebreaks/fire lines avoid the negative ecological impact of creating additional firebreaks. 
Burns at sites with firebreaks/fire lines pose less risk to people, buildings, or property.

Burns at sites with firebreaks/fire lines are easier to control.

Burns at sites with firebreaks/fire lines require less time or money invested.

Either I, or my agency, receives funding to burn sites based on whether they have firebreaks/fire lines.

Either I, or my agency, is mandated to burn sites with firebreaks/fire lines.

Firebreaks/fire lines make it easier to introduce fire into previously unburned sites.

If there are any other reasons why firebreaks/fire lines are important for determining burning priorities, please list them here.

\section{Ecosystem health}

Which of the following do you consider to be qualities of sites with good overall ecosystem health in longleaf pine communities in the Onslow Bight? Please choose all that apply.

High species richness (large number of species) in the understory

Presence of threatened or endangered species

Low shrub fuel load/open midstory

Open canopy

Old-growth canopy/trees on a long rotation

Frequently burned

Aesthetically pleasing

Other - please specify 
Why do you consider the overall ecosystem health of a site to be important for determining burn priorities? Please choose all that apply.

Either I, or my agency, is mandated to focus on overall ecosystem health.

Fire behavior is more predictable at sites with good ecosystem health.

Focusing on sites with GOOD ecosystem health ensures that burning results in ecological benefits.

Sites with good ecosystem health have lower fuel loads.

Focusing on sites with POOR ecosystem health ensures that burning results in ecological benefits.

Either I, or my agency, receives funding to focus on overall ecosystem health.

Smoke management is easier at sites with good ecosystem health than at other sites.

The public cares about the ecosystem health of sites.

If there are any other reasons why ecosystem health is important for determining burning priorities, please list them here.

\section{Undesired exotic or invasive plants}

Why do you consider the presence of undesired exotic or invasive plants at a site to be important for determining burn priorities? Please choose all that apply.

Burning sites with undesirable exotic or invasive plants makes smoke management easier in the future.

Either I, or my agency, is mandated to control undesirable exotic or invasive plants.

Burning sites WITHOUT undesirable exotic or invasive plants minimizes fire behavior on current burns.

Either I, or my agency, receives funding to control undesirable exotic or invasive plants. 
The public cares about burning sites with undesirable exotic or invasive plants.

Burning sites with undesirable exotic or invasive plants makes predicting fire behavior on future burns easier.

Burning sites with undesirable exotic or invasive plants improves habitat for native plants and/or wildlife.

Burning sites WITHOUT undesirable exotic or invasive plants makes smoke management easier on current burns.

Burning sites with undesirable exotic or invasive plants makes it easier to eradicate these plants.

If there are any other reasons why the presence of undesired exotic or invasive plants is important for determining burning priorities, please list them here.

\section{Proximity to other burned sites}

Why do you consider the proximity of a site to other burned sites to be important for determining burn priorities? Please choose all that apply.

Wildlife or plant populations benefit from restored habitat areas that are connected to, or near one another.

Burning sites that are near other burned sites makes planning ahead for future burns easier.

Burning sites that are near other burned sites makes controlling fires easier.

Either I, or my agency, is mandated to burn sites that are near other burned sites.

Smoke management is easier in sites that are near other burned sites.

Either I, or my agency, receives funding to burn sites that are near other burned sites.

Fewer resources (money, equipment, or personnel) are required to burn sites that are close to other burned sites. 
If there are any other reasons why proximity to other burned sites is important for determining burning priorities, please list them here.

Experienced fire historically or during presettlement

Why do you consider the historic fire frequency of a site to be important for determining burn priorities? Please choose all that apply.

Either I, or my agency, receives funding to burn based on the historical or presettlement condition of sites.

Fire behavior is easier to predict at sites that experienced frequent fire historically.

Burning based on historic fire frequency helps improve wildlife or plant habitat.

Smoke management is easier at sites that experienced frequent fire historically.

Burning based on historic fire frequency helps maintain or restore threatened or endangered species.

Either I, or my agency, is mandated to burn sites based on their historic fire frequency.

The public cares about restoring the presettlement or "natural" condition of sites.

Burning sites that have NOT experienced frequent fire historically results in more ecological benefits.

If there are any other reasons why historic fire frequency is important for determining burning priorities, please list them here. 


\section{Additional characteristics}

Please describe why $<$ Other Characteristic $1>$ is an important site characteristic for determining burning priorities.

Please describe why $<$ Other Characteristic $2>$ is an important site characteristic for determining burning priorities.

Please describe why $<$ Other Characteristic $3>$ is an important site characteristic for determining burning priorities.

Please describe why $<$ Other Characteristic $4>$ is an important site characteristic for determining burning priorities. 